\title{
NOX2-Derived Hydrogen Peroxide Impedes the AMPK/Akt-mTOR Signaling Pathway in Parkinson's Disease in Vitro Models
}

\section{Ruijie Zhang}

Nanjing Normal University

Nana Zhang

Nanjing Normal University

Xiaoqing Dong

Nanjing Normal University

\section{Xin Chen}

Nanjing Normal University

Jing $\mathrm{Ma}$

Nanjing Normal University

Wei Gao

Nanjing Normal University

Shile Huang

Louisiana State University Health Sciences Center

Long Chen ( $\square$ Ichen@njnu.edu.cn )

Nanjing Normal University https://orcid.org/0000-0002-2050-8050

\section{Research Article}

Keywords: NADPH oxidase 2, Hydrogen peroxide, AMPK, Akt, mTOR, Parkinson's disease

Posted Date: August 5th, 2021

DOl: https://doi.org/10.21203/rs.3.rs-767348/v1

License: (c) (1) This work is licensed under a Creative Commons Attribution 4.0 International License.

Read Full License 


\section{Abstract}

Oxidative stress is closely related to the pathogenesis of Parkinson's disease (PD), a typical neurodegenerative disease. NADPH oxidase 2 (NOX2) is involved in hydrogen peroxide $\left(\mathrm{H}_{2} \mathrm{O}_{2}\right)$ generation. Recently, we have reported that $\mathrm{H}_{2} \mathrm{O}_{2}$ and PD toxins, including 6-hydroxydopamine (6-OHDA), 1-Methyl-4phenylpyridin-1-ium (MPP ${ }^{+}$) and rotenone, induce neuronal apoptosis by inhibiting mTOR pathway. Here, we show that 6-OHDA, MPP ${ }^{+}$or rotenone induced $\mathrm{H}_{2} \mathrm{O}_{2}$ generation by upregulation of NOX2 and its regulatory proteins ( $\mathrm{p} 22^{\text {phox }}, \mathrm{p} 40^{\text {phox }}, \mathrm{p} 47^{\text {phox }}, \mathrm{p} 67^{\text {phox }}$, and Rac1), leading to apoptotic cell death in PC12 cells and primary neurons. Pretreatment with catalase, a $\mathrm{H}_{2} \mathrm{O}_{2}$-scavenging enzyme, significantly blocked PD toxins-evoked NOX2-derived $\mathrm{H}_{2} \mathrm{O}_{2}$, thereby hindering activation of AMPK, inhibition of Akt/mTOR, induction of apoptosis in neuronal cells. Similar events were also seen in the cells pretreated with MitoTEMPO, a mitochondria-specific superoxide scavenger, implying a mitochondrial $\mathrm{H}_{2} \mathrm{O}_{2}$-dependent mechanism involved. Further research revealed that inhibiting NOX2 with apocynin or silencing NOX2 attenuated the effects of PD toxins on AMPK/Akt/mTOR and apoptosis in the cells. Of importance, ectopic expression of constitutively active Akt or dominant negative AMPKa, or inhibition of AMPK with compound $\mathrm{C}$ suppressed PD toxins-induced expression of NOX2 and its regulatory proteins, as well as consequential $\mathrm{H}_{2} \mathrm{O}_{2}$ and apoptosis in the cells. Taken together, these results indicate that certain PD toxins can impede the AMPK/Akt-mTOR signaling pathway leading to neuronal apoptosis by eliciting NOX2-derived $\mathrm{H}_{2} \mathrm{O}_{2}$. Our findings suggest that neuronal loss in PD may be prevented by regulating of NOX2, AMPK/Akt-mTOR signaling and/or administering antioxidants to ameliorate oxidative stress.

\section{Introduction}

Parkinson's disease (PD) is a progressive neurodegenerative disease characterized by loss of dopamineproducing neurons in the ventral midbrain substantia nigra (SN) [1-3]. As the disease progresses, there exist the typical motor symptoms with bradykinesia, rigidity, impaired postural balance, a characteristic resting tremor, and consequential dementia in PD patients [4,5]. Overwhelming evidence has demonstrated that neuronal loss is linked to protein aggregation and oxidative stress [6], and especially oxidative stress is increasingly recognized as a central event contributing to the degeneration of dopaminergic neurons in the pathogenesis of PD [7]. It is well-known that oxidative stress is due to the disequilibrium between the production of reactive oxygen species (ROS) and the availability of antioxidants or radical scavengers, which creates a perilous state contributing to cellular damage $[5,8,9]$. ROS are conventionally considered cytotoxic byproducts of abnormal metabolism [10]. Excessive or sustained ROS can attack all macromolecules including lipids, proteins and nucleic acids, leading to defects in their physiological function and subsequent more ROS production and ultimately SN neuronal damage and death in PD $[5,9,10]$. Thus, understanding the underlying mechanisms by which oxidative stress contributes to the loss of dopaminergic neurons may help develop effective approaches in prevention and treatment of PD. 
NADPH-oxidases (NOXs) family has seven isoforms NOX1, NOX2, NOX3, NOX4, NOX5, DUOX1 and DUOX2, which share the capacity to transport electrons across the plasma membrane and to generate superoxide and other downstream ROS, such as hydrogen peroxide $\left(\mathrm{H}_{2} \mathrm{O}_{2}\right)$, in phagocytes and numerous nonphagocytic cells, including neurons [11-15]. NOX2, also known as gp9 ${ }^{\text {phox }}$, exists in close association with its regulatory protein $\mathrm{p} 22^{\text {phox }}$, a noncatalytic subunit, and is activated through interactions with other regulatory proteins $\mathrm{p} 40^{\text {phox }}, \mathrm{p} 47^{\mathrm{phox}}, \mathrm{p} 67^{\mathrm{phox}}$, and the small GTPase Rac1 as cytosolic subunits $[15,13]$. There exists high expression of NOX2 in the central nervous system (CNS), and especially abnormal activity of NOX2 causes excessive ROS production in PD $[15,13,16]$.

AMP-activated protein kinase (AMPK) is a key controller of energy homeostasis and cell survival in response to oxidative stress [17]. Emerged studies have documented that inactivation or activation of AMPK due to oxidative stress is implicated in neurodegenerative diseases [17-20]. The mammalian target of rapamycin (mTOR) senses and integrates a variety of environmental cues (growth factors, nutrients, and energy/oxidative stress) to control protein/lipid/nucleic acid synthesis,

cell growth/proliferation and survival, and is negatively regulated by AMPK [21]. Akt/protein kinase B (PKB) lies upstream of mTOR, so activated Akt may positively regulate mTOR, leading to increased phosphorylation of ribosomal p70 S6 kinase 1 (S6K1) and eukaryotic initiation factor 4E binding protein

1 (4E-BP1), two best characterized downstream effector molecules of mTOR [21]. Our group has observed that $\mathrm{H}_{2} \mathrm{O}_{2}$ inhibits mTOR signaling by activation of AMPK leading to apoptosis of neuronal cells [22]. PD toxins, such as 6-hydroxydopamine (6-OHDA), 1-Methyl-4-phenylpyridin-1-ium (MPP+) and rotenone, can activate AMPK and inactivate Akt, causing neuronal cell death via inhibiting mTORmediated S6K1 and 4E-BP1 pathways [23]. We have also demonstrated that rotenone triggers $\mathrm{H}_{2} \mathrm{O}_{2}$ dependent inhibition of mTOR pathway leading to neuronal apoptosis [24]. Here we show that upregulation of NOX2 and its regulatory proteins (p22 ${ }^{\text {phox }}, p 40^{\text {phox }}$, p47 $^{\text {phox }}$, p67 ${ }^{\text {phox }}$, and Rac1) contributes to excessive generation of $\mathrm{H}_{2} \mathrm{O}_{2}$ in $\mathrm{PD}$ in vitro models, which impedes the AMPK/Akt-mTOR signaling pathway leading to apoptotic cell death in neuronal cells. Our findings suggest that proper comanipulation of NOX2, AMPK/Akt-mTOR signaling and/or administration of antioxidants to ameliorate oxidative stress may be a potential strategy for prevention and treatment of PD.

\section{Materials And Methods}

\section{Materials}

Rotenone, 6-hydroxydopamine (6-OHDA), poly-D-lysine (PDL), 2'7'-dichlorodihydrofluorescein diacetate $\left(\mathrm{H}_{2}\right.$ DCFDA), 4',6-diamidino-2-phenylindole (DAPI), catalase (CAT), apocynin, and protease inhibitor cocktail were purchased from Sigma (St Louis, MO, USA). Mito-TEMPO was acquired from ALEXIS Biochemicals Corporation (San Diego, CA, USA). Compound C and 1-methyl-4-phenylpyridin-1-ium (MPP ${ }^{+}$) were provided by Calbiochem (San Diego, CA, USA). Dulbecco's Modified Eagle's Medium (DMEM), 0.05\% Trypsin-EDTA, NEUROBASAL ${ }^{\mathrm{T}}{ }^{\mathrm{M}}$ Media, and B27 Supplement were from Invitrogen (Grand Island, NY, USA). Horse serum and fetal bovine serum (FBS) were supplied by Hyclone (Logan, UT, USA). Enhanced 
chemiluminescence solution was from Sciben Biotech Company (Nanjing, China). The following antibodies were used: p-Akt (Ser473), p-Akt (Thr308), p-S6K1 (Thr389), p-4E-BP1 (Thr70), 4E-BP1, cleaved caspase-3 (Cell Signaling Technology, Danvers, MA, USA); $\beta$-tubulin, p-mTOR (Ser2448), mTOR, p-AMPKa (Thr172), AMPKa, p40 ${ }^{\text {phox }}$, p47 ${ }^{\text {phox }}$, HA (Sigma); Akt, S6K1, p22 ${ }^{\text {phox }}$ (Santa Cruz Biotechnology, Dallas, TX, USA); NOX2, p67 $7^{\text {phox }}$ (Epitomics, Burlingame, CA, USA), Rac1 (Cytoskeleton, Denver, CO, USA); Goat antirabbit IgG-horseradish peroxidase (HRP), goat anti-mouse IgG-HRP, and rabbit anti-goat lgG-HRP (Pierce, Rockford, IL, USA). Other chemicals were purchased from local commercial sources and were of analytical grade, unless stated elsewhere.

\section{Cell culture}

Rat pheochromocytoma (PC12) cell line (RRID: CVCL_0481) was obtained from American Type Culture Collection (ATCC) (Manassas, VA, USA). Because of the replicative nature and cost effectiveness, the cell line is widely used as neuronal cell models, so it was employed in this study. Cells, seeded in a 6-well plate $\left(5 \times 10^{5}\right.$ cells/well) or 96 -well plate $\left(1 \times 10^{4}\right.$ cells/well) pre-coated with $0.2 \mu \mathrm{g} / \mathrm{ml} \mathrm{PDL}$, were cultured in antibiotic-free DMEM supplemented with $10 \%$ horse serum and $5 \%$ FBS in a humidified incubator of $5 \%$ $\mathrm{CO}_{2}$ at $37^{\circ} \mathrm{C}$. To verify the data obtained from PC12 cells, primary neurons were also used in this study. For this, primary murine neurons were isolated from fetal mouse cerebral cortexes of 16-18 days of gestation in female ICR mice (being pregnant) as described [22], and seeded in a 6-well plate $\left(5 \times 10^{5}\right.$ cells/well) or 96 -well plate $\left(1 \times 10^{4}\right.$ cells/well) coated with $10 \mu \mathrm{g} / \mathrm{mL}$ PDL for experiments after 6 days of culture. All procedures used in this study were approved by the Institutional Animal Care and Use Committee, and were in compliance with the guidelines set forth by the Guide for the Care and Use of Laboratory Animals.

\section{Recombinant adenoviral constructs and infection of cells}

The recombinant adenoviral vectors encoding HA-tagged myristoylated, constitutively active Akt (Ad-myr-

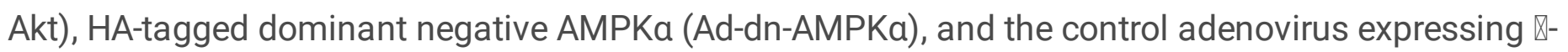
galactosidase (Ad-LacZ) were described previously [25,26,22]. The viruses were amplified, titrated and used as described [27,22]. For experiments, PC12 cells were cultured in the growth medium, and infected with the individual adenovirus for $24 \mathrm{~h}$ at 5 of multiplicity of infection $(\mathrm{MOI}=5)$. Subsequently, cells were used for experiments. Cells infected with Ad-LacZ alone served as a control. Expression of HA-tagged myr-Akt or dn-AMPKa was determined by Western blotting with antibodies to HA.

\section{Lentiviral shRNA cloning, production, and infection}

Lentiviral shRNAs to NOX2 and GFP (for control) were generated as described [25,28]. For use, a monolayer of $\mathrm{PC} 12$ cells, when grown to about $70 \%$ confluence, were infected with the corresponding lentivirus-containing medium in the presence of $8 \mathrm{mg} / \mathrm{ml}$ polybrene for $12 \mathrm{~h}$ twice at an interval of $6 \mathrm{~h}$. Uninfected cells were eliminated by exposure to $2 \mathrm{mg} / \mathrm{mL}$ puromycin for $48 \mathrm{~h}$ before use. After 5 days of culture, cells were used for experiments. 


\section{Assays for cell caspase-3/7 activity}

PC12 cells and primary neurons were seeded in a PDL-coated 96 -well plate $\left(1 \times 10^{4}\right.$ cells/well). The next day, cells were treated with/without 6-OHDA (30, 60 and/or $120 \mu \mathrm{M}), \mathrm{MPP}^{+}(0.5,1$ and/or $1.5 \mathrm{mM})$ or rotenone $(0.5,1 \mathrm{and} /$ or $2 \mu \mathrm{M})$ for 6,12 and/or $24 \mathrm{~h}$ with five replicates of each treatment. Subsequently, caspase-3/7 activity was detected using Caspase-Glo ${ }^{\circledR} 3 / 7$ Assay Kit (Promega, Madison, WI, USA), according to the manufacturer's protocol.

\section{DAPI staining}

PC12 cells and primary neurons, or PC12 cells infected with lentiviral shRNA to NOX2 or GFP, or PC12 cells infected with Ad-myr-Akt, Ad-dn-AMPKa or Ad-LacZ, respectively, were seeded at a density of $5 \times 10^{5}$ cells/well in a 6-well plate containing a PDL-coated glass coverslip per well. The next day, cells were treated with/without 6-OHDA (30, 60 and/or $120 \mu \mathrm{M}), \mathrm{MPP}^{+}(0.5,1$ and/or $1.5 \mathrm{mM})$ or rotenone $(0.5,1$ and/or $2 \mu \mathrm{M})$ for 6,12 and/or $24 \mathrm{~h}$, or treated with/without 6-OHDA $(120 \mu \mathrm{M}), \mathrm{MPP}^{+}(1 \mathrm{mM})$ or rotenone $(1 \mu \mathrm{M})$ for $24 \mathrm{~h}$ following pre-incubation with/without a H2O2-scavenging enzyme CAT (350 U/ml), a mitochondria-targeted antioxidant Mito-TEMPO $(10 \mu \mathrm{M})$, or a NOX2 inhibitor apocynin $(50 \mu \mathrm{M})$ for $1 \mathrm{~h}$, or an AMPK inhibitor compound $\mathrm{C}(20 \mu \mathrm{M})$ for $2 \mathrm{~h}$ with 5 replicates of each treatment. Afterwards, the cells with fragmented and condensed nuclei were determined using DAPI staining as described [29]. Finally, slides were mounted in glycerol/phosphate buffered saline (PBS) $(1: 1, \mathrm{v} / \mathrm{v})$ containing 2.5\% 1,4diazabiclo-(2,2,2) octane. Photographs were taken under a fluorescence microscope (Leica DMi8, Wetzlar, Germany) equipped with a digital camera.

\section{Intracellular H2O2 imaging}

Intracellular $\mathrm{H} 2 \mathrm{O} 2$ level was imaged by using a nonfluorescent probe, $\mathrm{H}_{2}$ DCFDA. This peroxide-selective dye can penetrate into the intracellular matrix of cells, where it is cleaved by intracellular esterases and oxidized by $\mathrm{H} 2 \mathrm{O} 2$ to form fluorescent DCF [30]. In brief, the indicated cells, after treatment as described above, were loaded with $\mathrm{H}_{2}$ DCFDA (20 $\left.\mathrm{LM}\right)$ for $1 \mathrm{~h}$. Subsequently, all stained specimens were rinsed three times with PBS, followed by imaging under a fluorescence microscope, and quantitatively measuring integral optical density (IOD) of the fluorescence intensity by Image-Pro Plus 6.0 software (Media Cybernetics Inc., Newburyport, MA, USA).

\section{Western blot analysis}

The indicated cells, after treatments, were briefly washed with cold PBS, and then on ice, lysed in the radioimmunoprecipitation assay buffer. Afterwards, Western blotting was performed as described previously [22].

\section{Statistical analysis}

All data were expressed as means \pm standard error of the mean (means \pm SEM). Student's $t$-test for nonpaired replicates was used to identify statistically significant differences between treatment means. 
Group variability and interaction were compared using either one-way or two-way ANOVA followed by Bonferroni's post-tests to compare replicate means. A level of $P<0.05$ was considered to be significant.

\section{Results}

\section{PD toxins induce $\mathrm{H}_{2} \mathrm{O}_{2}$ contributing to apoptosis by upregulating NOX2 and its regulatory proteins in neuronal cells}

It is well-known that NOX2 and its regulatory proteins $\left(\mathrm{p} 22^{\text {phox }}, \mathrm{p} 40^{\text {phox }}, \mathrm{p} 47^{\text {phox }}, \mathrm{p} 67^{\text {phox }}\right.$, and Rac1) are involved in $\mathrm{H}_{2} \mathrm{O}_{2}$ generation $[13,31]$. Our group has demonstrated that rotenone induces $\mathrm{H}_{2} \mathrm{O}_{2}$ leading to neuronal apoptosis [24]. Here, PD toxins (6-OHDA, MPP ${ }^{+}$and rotenone) were used to treat PC12 cells and primary neurons for 0-24 h or $24 \mathrm{~h}$, followed by Western blot analysis. We found that treatment with 6$\mathrm{OHDA}, \mathrm{MPP}^{+}$or rotenone upregulated the expression of NOX2, p22 ${ }^{\text {phox }}, \mathrm{p} 40^{\text {phox }}, \mathrm{p} 47^{\text {phox }}, \mathrm{p} 67^{\text {phox }}$ and Rac1 in a time- and dose-dependent manner in the cells (Fig. 1A and B). We also observed time- and dosedependent induction of intracellular $\mathrm{H}_{2} \mathrm{O}_{2}$ production by $6-\mathrm{OHDA}$, MPP ${ }^{+}$or rotenone (Fig. $1 \mathrm{C}-\mathrm{E}$ ), as evidenced by imaging (in green) (Fig. 1C) and quantifying (Fig. 1D and E) using a peroxide-selective probe, $\mathrm{H}_{2}$ DCFDA [30]. Sequentially, we investigated the cells with nuclear fragmentation and condensation, a hallmark of apoptosis [32], using DAPI staining, and the status of caspases $3 / 7$, using caspase $3 / 7$ activity assay, in PC12 cells and primary neurons. Imaged and quantified results revealed that $6-\mathrm{OHDA}, \mathrm{MPP}^{+}$or rotenone markedly increased the percentage of the cells with nuclear fragmentation and condensation (arrows) (Fig. 2A-C). In line with the above events, these PD toxins profoundly induced activation of caspases $3 / 7$ in the cells as well (Fig. 2D and E). Taken together, the results imply that PD toxins (6-OHDA, MPP ${ }^{+}$or rotenone) might induce $\mathrm{H}_{2} \mathrm{O}_{2}$ contributing to apoptosis by upregulating NOX2 and its regulatory proteins in neuronal cells.

\section{PD toxins' induction of intracellular and mitochondrial $\mathrm{H} 2 \mathrm{O} 2$ hinders AMPK/Akt-mTOR signaling pathway leading to apoptosis in neuronal cells}

Our group previously found that PD toxins activate AMPK and inactivate Akt, causing neuronal apoptosis via inhibiting the mTOR signaling pathway [23]. Therefore, we sought to validate whether the toxinsimpaired AMPK/Akt-mTOR signaling pathway leading to neuronal apoptosis is due to induction of intracellular $\mathrm{H}_{2} \mathrm{O}_{2}$. For this, catalase (CAT), a H2O2-scavenging enzyme, was employed. The results showed that pretreatment with CAT strikingly blocked 6-OHDA-, MPP ${ }^{+}$- or rotenone-induced upregulation of NOX2 and its regulatory proteins, as well as generation of $\mathrm{H} 2 \mathrm{O} 2$ in $\mathrm{PC} 12$ cells and primary neurons (Fig. 3A and B). Of importance, CAT rescued the cells from PD toxins-elicited increase in p-AMPKa and decrease in p-Akt, p-mTOR, p-S6K1 and p-4E-BP1 (Fig. 3C). CAT also profoundly diminished the activation of caspases-3 and the number of fragmented nuclear cells in the cells exposed to the PD toxins (Fig. 3C and D). The findings support that the PD toxins induce intracellular $\mathrm{H} 2 \mathrm{O} 2$, which mediates the AMPK/AktmTOR signaling pathway leading to apoptosis by upregulating NOX2 and its regulatory proteins in neuronal cells. 
Next, we studied whether the effects of PD toxins on AMPK/Akt-mTOR and apoptosis are related to excessive $\mathrm{H}_{2} \mathrm{O}_{2}$ production in the mitochondria of neuronal cells. To this end, PC12 cells and primary neurons were pretreated with/without a mitochondria-targeted antioxidant Mito-TEMPO $(10 \mu \mathrm{M})$ for $1 \mathrm{~h}$, and then exposed to 6-OHDA $(120 \mu \mathrm{M}), \mathrm{MPP}^{+}(1 \mathrm{mM})$ or rotenone $(1 \mu \mathrm{M})$ for $24 \mathrm{~h}$. The results showed that pretreatment with Mito-TEMPO powerfully mitigated exorbitant expression of NOX2 and its regulatory proteins, as well as excessive $\mathrm{H}_{2} \mathrm{O}_{2}$ production in the cells induced by the PD toxins (Fig. $4 \mathrm{~A}$ and B). Consistently, Mito-TEMPO substantially reversed 6-OHDA-, MPP ${ }^{+}$- or rotenone-triggered increase of p-AMPKa and decreases of p-Akt, p-mTOR, p-S6K1 and p-4E-BP1 (Fig. 4C), as well as cleavage of caspases-3 and apoptosis in the cells (Fig. 4C and D). The results indicate that the PD toxins indeed evoke mitochondrial H2O2, which impairs the AMPK/Akt-mTOR signaling pathway leading to apoptosis by upregulating NOX2 and its regulatory proteins in neuronal cells.

\section{PD toxins activate AMPK and inactivate Akt, resulting in inhibition of mTOR-mediated S6K1 and 4E-BP1 pathways, as well as apoptosis by a NOX2-dependent mechanism in neuronal cells}

To pinpoint whether the effects of PD toxins on AMPK/Akt-mTOR and apoptosis are attributed to the activation of NOX2, apocynin, an inhibitor of NOXs [33], was employed. The results showed that apocynin $(50 \mu \mathrm{M})$ obviously suppressed 6-OHDA-, $\mathrm{MPP}^{+}$- or rotenone-induced upregulation of NOX2 and generation of $\mathrm{H} 2 \mathrm{O} 2$ in PC12 cells and primary neurons (Fig. 2A and B). PD toxins-induced activation of AMPK and inactivation of Akt, as well as consequential inhibition of mTOR-mediated S6K1 and 4E-BP1 pathways were reversed by pretreatment with apocynin in the cells (Fig. 5A). In line with this, apocynin also potently attenuated PD toxins-induced cleavage of caspase-3 and apoptosis in the cells (Fig. 5A and C).

To further corroborate the role of NOX2 in the PD toxins-induced activation of AMPK, inhibition of AktmTOR signaling pathway and neuronal apoptosis, PC12 cells, infected with lentiviral shRNA to NOX2 or GFP, were exposed to 6-OHDA $(120 \mu \mathrm{M}), \mathrm{MPP}^{+}(1 \mathrm{mM})$ or rotenone $(1 \mu \mathrm{M})$ for $24 \mathrm{~h}$. As shown in Fig. 5D, NOX2 expression was downregulated by $~ 90 \%$ in shRNA NOX2-infected cells compared to shRNA GFPinfected cells. Knockdown of NOX2 did not affect the basal phosphorylation of AMPKa, Akt, mTOR, S6K1 and 4E-BP1, and cleavage of caspase-3. However, silencing NOX2 remarkably suppressed 6-OHDA-, $\mathrm{MPP}^{+}$- or rotenone-induced increase of p-AMPKa and decreases of p-Akt, p-mTOR, p-S6K1 and p-4E-BP1 (Fig. 5D). Consistently, depleting NOX2 also potently attenuated PD toxins-elicited cleavage of caspase-3 (Fig. 5D), H2O2 production (Fig. 5E), and apoptosis (Fig. 5F) in the cells. Taken together, these data verify that the PD toxins activate AMPK and inactivate Akt, resulting in inhibition of mTOR-mediated S6K1 and 4E-BP1 pathways, as well as apoptosis through a NOX2-dependent mechanism in neuronal cells.

\section{Modulation of Akt and AMPK activity interferes with PD toxins' induction of NOX2-derived H2O2 and apoptosis in neuronal cells}

To investigate whether modulation of Akt activity impacts on NOX2-derived $\mathrm{H} 2 \mathrm{O} 2$ and apoptosis in neuronal cells in response to PD toxins, a recombinant adenovirus expressing HA-tagged myristoylated constitutively active Akt (Ad-myr-Akt) was employed. We observed that ectopic expression of myr-Akt 
partially prevented PC12 cells from upregulation of NOX2, p22 ${ }^{\text {phox }}, \mathrm{p}^{\text {phox }}, \mathrm{p} 47^{\text {phox }}, \mathrm{p} 67^{\text {phox }}$ and Rac1, as well as excessive $\mathrm{H}_{2} \mathrm{O}_{2}$ production induced by $6-\mathrm{OHDA}, \mathrm{MPP}^{+}$or rotenone (Fig. $6 \mathrm{~A}$ and $\mathrm{B}$ ). Of importance, overexpression of myr-Akt potently rendered resistance to the $\mathrm{PD}$ toxins-induced apoptosis (Fig. $6 \mathrm{C}$ ) in the cells.

To gain more insights into the role and significance of AMPK in inducing NOX2-derived $\mathrm{H} 2 \mathrm{O} 2$ and neuronal apoptosis by PD toxins, PC12 cells and primary neurons were pretreated with/without AMPK inhibitor compound $\mathrm{C}(20 \mu \mathrm{M})$ for $2 \mathrm{~h}$ and then exposed to 6-OHDA $(120 \mu \mathrm{M}), \mathrm{MPP}^{+}(1 \mathrm{mM})$ or rotenone $(1 \mu \mathrm{M})$ for $24 \mathrm{~h}$. As demonstrated in Fig. 7A and $\mathrm{B}, 6-\mathrm{OHDA}, \mathrm{MPP}^{+}$or rotenone markedly evoked the elevation of $\mathrm{p}-\mathrm{AMPKa}$, and the upregulation of NOX2, p22 ${ }^{\text {phox }}, \mathrm{p} 40^{\text {phox }}, \mathrm{p} 47^{\text {phox }}, \mathrm{p} 67^{\text {phox }}$ and Rac1, as well as the increase of $\mathrm{H}_{2} \mathrm{O}_{2}$ production. The effects were substantially attenuated in the cells pretreated with compound C (Fig. 7A and B). Sequentially, we also observed that addition of compound C conferred high resistance to the PD toxins-induced neuronal apoptosis (Fig. 7C). These results support the idea that PD toxins induce NOX2-derived $\mathrm{H} 2 \mathrm{O} 2$ and apoptosis in part by activating AMPK in neuronal cells.

To confirm the above findings, PC12 cells, infected with recombinant adenoviruses expressing HA-tagged dominant negative AMPKa1 (Ad-dn-AMPKa) and control adenovirus expressing $\beta$-galactosidase alone (Ad-LacZ), respectively, were exposed to 6-OHDA $(120 \mu \mathrm{M}), \mathrm{MPP}^{+}(1 \mathrm{mM})$ or rotenone $(1 \mu \mathrm{M})$ for $24 \mathrm{~h}$. As expected, a high level of HA-tagged dn-AMPKa was seen in Ad-dn-AMPKa-infected cells, but not in AdLacZ-infected cells (control) (Fig. 7D). Ectopic expression of dn-AMPKa almost completely blocked the AMPK activity, since the basal or the PD toxins-inhibited p-AMPK was substantially suppressed (Fig. 7D). Of importance, expression of dn-AMPKa markedly reversed 6-OHDA-, MPP ${ }^{+}$- or rotenone-triggered increase in NOX2, p22 ${ }^{\text {phox }}, \mathrm{p} 40^{\text {phox }}, \mathrm{p} 47^{\text {phox }}$, p6 $7^{\text {phox }}, \mathrm{Rac} 1, \mathrm{H}_{2} \mathrm{O}_{2}$ production and apoptosis in the cells (Fig. 7D-F). Taken together, our data demonstrate the importance of PD toxins-activated AMPKa in their induction of NOX2-derived $\mathrm{H} 2 \mathrm{O} 2$ and neuronal apoptosis.

\section{Discussion}

$P D$ is a neurodegenerative disease characterized by a major loss of dopaminergic nigrostriatal neurons [1-3]. A large number of reports have pointed to the close relationship of oxidative stress, e.g., ROS, as a critical etiological factor of neuronal loss, to pathogenesis of PD [7, 6, 34]. Excessive intracellular ROS can directly oxidize lipids, proteins, and nucleic acids, and thus activate or inhibit related signaling pathways, thereby leading to damage of the basic cell structures and consequential CNS dysfunction [5, $9,20,22,34]$. Our previous studies have shown that PD toxins, including 6-OHDA, MPP ${ }^{+}$and rotenone, inhibit mTOR-mediated S6K1 and 4E-BP1 pathways leading to neuronal cell death through activating AMPK and inactivating Akt [23]. However, the underlying mechanism remains enigmatic. Here we present evidence that the PD toxins induced upregulation of NOX2, p22 ${ }^{\text {phox }}, \mathrm{p} 40^{\text {phox }}, \mathrm{p} 47^{\text {phox }}, \mathrm{p}^{\text {phox }}$, and Rac1, as well as excessive generation of $\mathrm{H}_{2} \mathrm{O}_{2}$, resulting in apoptosis in PC12 cells and primary neurons. Further, we found that the PD toxins-induced $\mathrm{H} 2 \mathrm{O} 2$ inhibited the mTOR pathway, at least in part by 
activating the negative regulator AMPKa [21] and concurrently by inhibiting the positive regulator Akt [21], leading to apoptosis of the neuronal cells.

There are many sources of ROS, and one of the major sources is attributed to the generation by the NOXs family, including NOX1, NOX2, NOX3, NOX4, NOX5, DUOX1 and DUOX2 enzymes $[13,10]$. Among them, NOX2 is the most abundant and widely expressed in phagocytes and numerous nonphagocytic cells [1115]. NOX2, as a catalytic subunit, interacts with a noncatalytic subunit $p 22^{\text {phox }}$ transmembrane protein along with the cytosolic subunits $p 40^{\text {phox }}$, p4 $7^{\text {phox }}$, p6 $7^{\text {phox }}$ and Rac $1[15,13,35]$. It is known that NOX2 is highly expressed in cells throughout the CNS, and ROS generation by NOX2 is implicated in a variety of neurological disorders, including PD, Alzheimer's disease (AD), Huntington's disease (HD), amyotrophic lateral sclerosis (ALS) and multiple sclerosis (MS) $[15,13,16,35]$. Rotenone induces $\mathrm{ROS} / \mathrm{H}_{2} \mathrm{O}_{2}$ contributing to apoptosis in neuronal cells [24], yet the underlying mechanism is poorly defined. Here, for the first time, we show that, on the one hand, induction of $\mathrm{H}_{2} \mathrm{O}_{2}$ generation by $6-\mathrm{OHDA}, \mathrm{MPP}^{+}$or rotenone was closely related to upregulated expression of the $\mathrm{H}_{2} \mathrm{O}_{2}$-generating enzyme NOX2 and its regulatory proteins, as well as neuronal apoptosis (Figs. 1 and 2); on the other hand, PD toxins-induced $\mathrm{H}_{2} \mathrm{O}_{2}$ stimulated the expression of NOX2 family members, because treatment with CAT, a $\mathrm{H}_{2} \mathrm{O}_{2}$-scavenging enzyme, abolished PD toxins-induced $\mathrm{H}_{2} \mathrm{O}_{2}$ and also negated PD toxins-induced expression of NOX2, p22 ${ }^{\text {phox }}, \mathrm{p} 40^{\text {phox }}, \mathrm{p} 47^{\text {phox }}, \mathrm{p} 67^{\text {phox }}$, and Rac1, as well as apoptosis in the cells (Fig. 3 ). The results imply a positive feedback loop involved in the regulation of the $\mathrm{H}_{2} \mathrm{O}_{2}$ prouction and NOX2 activity.

Mitochondria are significant contributors to ROS generation [5]. Any dysfunction of this cell organelle can be harmful to cell function and viability, as seen in $\operatorname{PD}[5,9,7]$. For example, mitochondrial dysfunction leads to excessive ROS production that is detrimental for dopaminergic SN cells [7, 5]. 6-OHDA, MPP ${ }^{+}$or rotenone evokes ROS generation by inhibiting mitochondrial complex I [9, 24, 36]. There exists a much enhanced $\mathrm{H}_{2} \mathrm{O}_{2}$ formation in mitochondria in situ in isolated nerve terminals when mitochondrial complex I is inhibited at a small degree [37]. In the present study, to evaluate the association of PD toxins-induced mitochondrial $\mathrm{H}_{2} \mathrm{O}_{2}$ generation with neuronal apoptosis, mitochondria-targeted antioxidant Mito-TEMPO [38] was employed. We found that administration of Mito-TEMPO dramatically diminished $\mathrm{H}_{2} \mathrm{O}_{2}$ and cell apoptosis in PC12 cells and primary neurons triggered by 6-OHDA, MPP ${ }^{+}$or rotenone (Fig. 4). Meanwhile, Mito-TEMPO also powerfully interrupted the expression of NOX2, p22 ${ }^{\text {phox }}, \mathrm{p} 40^{\text {phox }}, \mathrm{p} 47^{\text {phox }}, \mathrm{p}^{7^{\text {phox }}}$, and Rac1 in the cells in response to $6-\mathrm{OHDA} \mathrm{MPP}^{+}$or rotenone (Fig. 4). The findings suggest a mitochondrial $\mathrm{H}_{2} \mathrm{O}_{2}$-dependent mechanism involved. Collectively, our data support intracellular and mitochondrial $\mathrm{H}_{2} \mathrm{O}_{2}-$ dependent neuronal apoptosis, which may be implicated in abnormal status of NOX2-derived $\mathrm{H}_{2} \mathrm{O}_{2}$, in the context of PD.

In this study, we also found that CAT and Mito-TEMPO conferred high resistance to 6-OHDA-, MPP ${ }^{+}$- or rotenone-induced activation of AMPK, inactivation of Akt, inhibition of mTOR-mediated S6K1 and 4E-BP1 pathways, and increase of cleaved-caapase-3 (Fig. 3C and 4C), respectively, suggesting that the PD toxins' induction of intracellular and mitochondrial H2O2 activates AMPK and hinders Akt-mTOR 
signaling pathway leading to apoptosis in neuronal cells. Next, we asked whether 6-OHDA-, MPP ${ }^{+}$- or rotenone-impaired AMPK/Akt-mTOR signaling pathway was due to abnormal manifestation of NOX2derived $\mathrm{H}_{2} \mathrm{O}_{2}$ in neuronal cells induced by the PD toxins. For this, apocynin, a pharmacological inhibitor for ROS-generating enzyme NOX activity by blocking the assembly of NOX complex [39, 33], was used. The results showed that apocynin $(50 \mu \mathrm{M})$ effectively suppressed 6-OHDA-, MPP ${ }^{+}$- or rotenone-stimulated NOX2 activation and $\mathrm{H}_{2} \mathrm{O}_{2}$ generation (Fig. $5 \mathrm{~A}$ and $\mathrm{B}$ ). Of importance, inhibition of NOX2 with apocynin substantially suppressed 6-OHDA-, MPP ${ }^{+}$- or rotenone-induced activation of AMPK, inactivation of Akt, inhibition of mTOR-mediated S6K1 and 4E-BP1 pathways, increase of cleaved-caapase-3 and apoptosis in PC12 cells and primary neurons (Fig. 5A and C). This was further supported by the observations in NOX2-knockdown cells (Fig. 5D-F). Taking these findings into account, we deduce that PD toxins trigger NOX2-derived $\mathrm{H}_{2} \mathrm{O}_{2}$ generation impeding the AMPK/Akt-mTOR signaling pathway and consequentially resulting in apoptosis in neuronal cells.

AMPK and Akt are respectively negative and positive regulators of $\mathrm{mTOR}$, and especially their regulation of mTOR plays a key role in cell survival $[21,40,41,17]$. The observations from our group and other researchers have demonstrated that 6-OHDA-, MPP ${ }^{+}$- and/or rotenone-induced neuronal cell death is associated with or through AMPK activation and/or Akt inactivation $[42,2,23]$. In the current study, we further confirmed the events, as ectopic expression of constitutively active Akt (myr-Akt) or dominant negative AMPKa (dn-AMPK), or inhibition of AMPKa with compound $C$ markedly rescued from 6-OHDA-, $\mathrm{MPP}^{+}$- or rotenone-induced apoptosis in PC12 cells and/or primary neurons (Figs. 6 and 7). However, interestingly, we noticed that modulation of Akt and AMPK activity by RNA interference or pharmacological inhibition rendered a high resistance to 6-OHDA-, MPP ${ }^{+}$- or rotenone-upregulated NOX2, p22 ${ }^{\text {phox }}, p 40^{\text {phox }}, p 47^{\text {phox }}, p 67^{\text {phox }}$, and Rac1, as well as $\mathrm{H}_{2} \mathrm{O}_{2}$ generation in the cells (Figs. 6 and 7), suggesting that activated AMPK or deactivated Akt may feedback upregulate the PD toxins-stimulated NOX2 and its regulatory proteins, as well as $\mathrm{H}_{2} \mathrm{O}_{2}$. The findings enhance our understanding of PD toxinsstimulated $\mathrm{H}_{2} \mathrm{O}_{2}$-generating enzyme NOX2 and its regulatory proteins, which is vital for PD toxins-induced activation of AMPK, deactivation of Akt, and thus neuronal apoptosis, and provide an expanded conceptual view of blocking NOX2-derived $\mathrm{H}_{2} \mathrm{O}_{2}$ in the prevention and treatment of PD.

In conclusion, we have identified that PD toxins upregulate the expression of $\mathrm{H}_{2} \mathrm{O}_{2}$-generating NOX2 and its regulatory proteins, and thus evoke intracellular $\mathrm{H}_{2} \mathrm{O}_{2}$ and concomitant mitochondrial $\mathrm{H}_{2} \mathrm{O}_{2}$. This results in activation of AMPK and inhibition of the Akt-mTOR pathway, leading to apoptosis by in neuronal cells (Fig. 8). Our results highlight PD stresses impedes the AMPK/Akt-mTOR signaling pathway causing neuronal apoptosis by eliciting NOX2-derived $\mathrm{H}_{2} \mathrm{O}_{2}$, and suggest that proper co-manipulation of NOX2, AMPK/Akt-mTOR signaling and/or administration of antioxidants to ameliorate oxidative stress may be a potential strategy for prevention and treatment of PD.

\section{Abbreviations}


4E-BP1, eukaryotic initiation factor $4 \mathrm{E}$ binding protein 1; 6-OHDA, 6-hydroxydopamine; ACC, acetyl-CoA carboxylase; AD, Alzheimer disease; AMPK, AMP-dependent/activated protein kinase; CAT, catalase; DAPI, 4',6-diamidino-2-phenylindole; DMEM, Dulbecco's Modified Eagle's Medium; FBS, fetal bovine serum; HA, hemagglutinin; $\mathrm{HD}$, Huntington's disease; $\mathrm{H}_{2}$ DCFDA, 2'7'-dichlorodihydrofluorescein diacetate; $\mathrm{H}_{2} \mathrm{O}_{2}$, hydrogen peroxide; MPP+ ${ }^{+}$1-Methyl-4-phenylpyridin-1-ium; mTOR, mammalian target of rapamycin; PARP, poly ADP-ribose polymerase; PDL, poly-D-lysine; NOX2, NADPH oxidase 2; PBS, phosphate buffered saline; PD, Parkinson disease; PDL, poly-D-lysine; PI3K, phosphatidylinositol 3'-kinase; Akt (PKB), protein kinase B; ROS, reactive oxygen species; S6K1, ribosomal p70 S6 kinase 1; Ser/Thr, serine/threonine

\section{Declarations}

\section{Acknowledgements}

Not applicable

\section{Funding}

This work was supported in part by the grants from National Natural Science Foundation of China (No. 81873781, 81271416; LC), National Institutes of Health (CA115414; SH), Project for the Priority Academic Program Development of Jiangsu Higher Education Institutions of China (PAPD-14KJB180010; LC), BSKY Scientific Research from Anhui Medical University (XJ201813, RZ), and American Cancer Society (RSG08-135-01-CNE; SH).

\section{Author information}

\section{Affiliations}

Jiangsu Key Laboratory for Molecular and Medical Biotechnology, College of Life Sciences, Nanjing Normal University, Nanjing 210023, PR China

Ruijie Zhang, Nana Zhang, Xiaoqing Dong, Xin Chen, Jing Ma, Wei Gao \& Long Chen'

College of Life Sciences, Anhui Medical University, Anhui 230032, PR China

Ruijie Zhang

Department of Biochemistry and Molecular Biology, Louisiana State University Health Sciences Center, Shreveport, LA 71130-3932, USA

Shile Huang

Feist-Weiller Cancer Center, Louisiana State University Health Sciences Center, Shreveport, LA 711303932, USA 
Shile Huang

\section{Authors' contributions}

LC and SH conceived the project. ZR, SH and LC designed the experiments. ZR and ZN performed the experiments. ZR, ZN, SH and LC analyzed the data. DX, CX, MJ and HX contributed reagents/materials/analysis tools. ZR, SH and LC wrote the paper. All authors read and approved the final manuscript.

\section{Corresponding authors}

Correspondence to Long Chen or Shile Huang.

\section{Ethics declarations}

\section{Conflict of interest}

The authors declared that there are no conflicts of interests.

\section{Ethical approval for experiments using animal material}

The experiments involving animals in this study were handled in accordance with the guidelines of the Institutional Animal Care and Use Committee, and were in compliance with the guidelines set forth by the Guide for the Care and Use of Laboratory Animals.

\section{Data availability}

The data used to support the findings of this study are available from the corresponding author upon reasonable request.

\section{Consent to participate}

Not applicable

\section{Consent for publication}

Not applicable

\section{References}

1. Choi DH, Cristovao AC, Guhathakurta S, Lee J, Joh TH, Beal MF, Kim YS (2012) NADPH oxidase 1mediated oxidative stress leads to dopamine neuron death in Parkinson's disease. Antioxid Redox Signal 16 (10):1033-1045. https://doi.org/10.1089/ars.2011.3960.

2. Malagelada C, Jin ZH, Greene LA (2008) RTP801 is induced in Parkinson's disease and mediates neuron death by inhibiting Akt phosphorylation/activation. J Neurosci 28 (53):14363-14371. 
https://doi.org/10.1523/JNEUROSCI.3928-08.2008.

3. Maiti P, Manna J, Dunbar GL (2017) Current understanding of the molecular mechanisms in Parkinson's disease: Targets for potential treatments. Transl Neurodegener 6:28. https://doi.org/10.1186/s40035-017-0099-z.

4. Moustafa AA, Chakravarthy S, Phillips JR, Crouse JJ, Gupta A, Frank MJ, Hall JM, Jahanshahi M (2016) Interrelations between cognitive dysfunction and motor symptoms of Parkinson's disease: behavioral and neural studies. Rev Neurosci 27 (5):535-548. doi.org/10.1515/revneuro-2015-0070. https://doi.org/10.1515/revneuro-2015-0070.

5. Zaman V, Shields DC, Shams R, Drasites KP, Matzelle D, Haque A, Banik NL (2021) Cellular and molecular pathophysiology in the progression of Parkinson's disease. Metab Brain Dis 36 (5):815827. https://doi.org/10.1007/s11011-021-00689-5.

6. Trist BG, Davies KM, Cottam V, Genoud S, Ortega R, Roudeau S, Carmona A, De Silva K, Wasinger V, Lewis SJG, Sachdev P, Smith B, Troakes C, Vance C, Shaw C, AI-Sarraj S, Ball HJ, Halliday GM, Hare DJ, Double KL (2017) Amyotrophic lateral sclerosis-like superoxide dismutase 1 proteinopathy is associated with neuronal loss in Parkinson's disease brain. Acta Neuropathol 134 (1):113-127. https://doi.org/10.1007/s00401-017-1726-6.

7. Guo JD, Zhao X, Li Y, Li GR, Liu XL (2018) Damage to dopaminergic neurons by oxidative stress in Parkinson's disease (Review). Int J Mol Med 41 (4):1817-1825. https://doi.org/10.3892/ijmm.2018.3406.

8. Forrester SJ, Kikuchi DS, Hernandes MS, Xu Q, Griendling KK (2018) Reactive Oxygen Species in Metabolic and Inflammatory Signaling. Circ Res 122 (6):877-902. https://doi.org/10.1161/CIRCRESAHA.117.311401.

9. Dias V, Junn E, Mouradian MM (2013) The role of oxidative stress in Parkinson's disease. J Parkinsons Dis 3 (4):461-491. https://doi.org/10.3233/JPD-130230.

10. Lin CS, Lee SH, Huang HS, Chen YS, Ma MC (2015) H2O2 generated by NADPH oxidase 4 contributes to transient receptor potential vanilloid 1 channel-mediated mechanosensation in the rat kidney. Am J Physiol-Renal 309 (4):F369-376. https://doi.org/10.1152/ajprenal.00462.2014.

11. Block K, Gorin Y (2012) Aiding and abetting roles of NOX oxidases in cellular transformation. Nat Rev Cancer 12 (9):627-637. doi.org/10.1038/nrc3339.

12. Olguin-Albuerne M, Moran J (2015) ROS produced by NOX2 control in vitro development of cerebellar granule neurons development. ASN Neuro 7 (2). https://doi.org/10.1177/1759091415578712.

13. Bedard K, Krause KH (2007) The NOX family of ROS-generating NADPH oxidases: physiology and pathophysiology. Physiol Rev 87 (1):245-313. https://doi.org/10.1152/physrev.00044.2005.

14. Frey RS, Ushio-Fukai M, Malik AB (2009) NADPH oxidase-dependent signaling in endothelial cells: role in physiology and pathophysiology. Antioxid Redox Sign 11 (4):791-810. https://doi.org/10.1089/ars.2008.2220.

15. Brown DI, Griendling KK (2009) Nox proteins in signal transduction. Free Radic Biol Med 47 (9):12391253. https://doi.org/10.1016/j.freeradbiomed.2009.07.023. 
16. Koppula S, Kumar H, Kim IS, Choi DK (2012) Reactive oxygen species and inhibitors of inflammatory enzymes, NADPH oxidase, and iNOS in experimental models of Parkinson's disease. Mediat Inflamm 2012:823902. https://doi.org/10.1155/2012/823902.

17. Chiang MC, Nicol CJ, Cheng YC (2018) Resveratrol activation of AMPK-dependent pathways is neuroprotective in human neural stem cells against amyloid-beta-induced inflammation and oxidative stress. Neurochem Int 115:1-10. https://doi.org/10.1016/j.neuint.2017.10.002.

18. Jiang HL, Jin JZ, Wu D, Xu D, Lin GF, Yu H, Ma DY, Liang J (2013) Celastrol exerts synergistic effects with PHA-665752 and inhibits tumor growth of c-Met-deficient hepatocellular carcinoma in vivo. Mol Biol Rep 40 (7):4203-4209. https://doi.org/10.1007/s11033-013-2501-y.

19. Vingtdeux V, Chandakkar P, Zhao H, d'Abramo C, Davies P, Marambaud P (2011) Novel synthetic small-molecule activators of AMPK as enhancers of autophagy and amyloid-beta peptide degradation. FASEB J 25 (1):219-231. https://doi.org/10.1096/fj.10-167361.

20. Chen L, Xu B, Liu L, Luo Y, Zhou H, Chen W, Shen T, Han X, Kontos CD, Huang S (2011) Cadmium induction of reactive oxygen species activates the mTOR pathway, leading to neuronal cell death. Free Radic Biol Med 50 (5):624-632. https://doi.org/10.1016/j.freeradbiomed.2010.12.032.

21. Liu GY, Sabatini DM (2020) mTOR at the nexus of nutrition, growth, ageing and disease. Nat Rev Mol Cell Biol 21 (4):183-203. https://doi.org/10.1038/s41580-019-0199-y.

22. Chen L, Xu B, Liu L, Luo Y, Yin J, Zhou H, Chen W, Shen T, Han X, Huang S (2010) Hydrogen peroxide inhibits mTOR signaling by activation of AMPKalpha leading to apoptosis of neuronal cells. Lab Invest 90 (5):762-773. https://doi.org/10.1038/labinvest.2010.36.

23. Xu Y, Liu C, Chen S, Ye Y, Guo M, Ren Q, Liu L, Zhang H, Xu C, Zhou Q, Huang S, Chen L (2014) Activation of AMPK and inactivation of Akt result in suppression of mTOR-mediated S6K1 and 4EBP1 pathways leading to neuronal cell death in in vitro models of Parkinson's disease. Cell Signal 26 (8):1680-1689. https://doi.org/10.1016/j.cellsig.2014.04.009.

24. Zhou Q, Liu C, Liu W, Zhang H, Zhang R, Liu J, Zhang J, Xu C, Liu L, Huang S, Chen L (2015) Rotenone induction of hydrogen peroxide inhibits mTOR-mediated S6K1 and 4E-BP1/elF4E pathways, leading to neuronal apoptosis. Toxicol Sci 143 (1):81-96. https://doi.org/10.1093/toxsci/kfu211.

25. Liu L, Li F, Cardelli JA, Martin KA, Blenis J, Huang S (2006) Rapamycin inhibits cell motility by suppression of mTOR-mediated S6K1 and 4E-BP1 pathways. Oncogene 25 (53):7029-7040. https://doi.org/10.1038/sj.onc.1209691.

26. Fujio Y, Guo K, Mano T, Mitsuuchi Y, Testa JR, Walsh K (1999) Cell cycle withdrawal promotes myogenic induction of Akt, a positive modulator of myocyte survival. Mol Cell Biol 19 (7):5073-5082. https://doi.org/10.1128/MCB.19.7.5073.

27. Liu L, Chen L, Chung J, Huang S (2008) Rapamycin inhibits F-actin reorganization and phosphorylation of focal adhesion proteins. Oncogene 27 (37):4998-5010. https://doi.org/10.1038/onc.2008.137. 
28. Xu C, Wang X, Gu C, Zhang H, Zhang R, Dong X, Liu C, Hu X, Ji X, Huang S, Chen L (2017) Celastrol ameliorates $\mathrm{Cd}$-induced neuronal apoptosis by targeting NOX2-derived ROS-dependent PP5-JNK signaling pathway. J Neurochem 141 (1):48-62. https://doi.org/10.1111/jnc.13966.

29. Chen L, Liu L, Luo Y, Huang S (2008) MAPK and mTOR pathways are involved in cadmium-induced neuronal apoptosis. J Neurochem 105 (1):251-261. https://doi.org/10.1111/j.14714159.2007.05133.x.

30. Bao L, Avshalumov MV, Rice ME (2005) Partial mitochondrial inhibition causes striatal dopamine release suppression and medium spiny neuron depolarization via $\mathrm{H} 2 \mathrm{O} 2$ elevation, not ATP depletion. J Neurosci 25 (43):10029-10040. https://doi.org/10.1523/JNEUROSCI.2652-05.2005.

31. Bertolotti M, Farinelli G, Galli M, Aiuti A, Sitia R (2016) AQP8 transports NOX2-generated H2O2 across the plasma membrane to promote signaling in B cells. J Leukoc Biol 100 (5):1071-1079. https://doi.org/10.1189/jlb.2AB0116-045R.

32. Hao B, Cheng S, Clancy CJ, Nguyen MH (2013) Caspofungin kills Candida albicans by causing both cellular apoptosis and necrosis. Antimicrob Agents Ch 57 (1):326-

332. https://doi.org/10.1128/AAC.01366-12.

33. Touyz RM (2008) Apocynin, NADPH oxidase, and vascular cells: a complex matter. Hypertension 51 (2):172-174. https://doi.org/10.1161/HYPERTENSIONAHA.107.103200.

34. Yeung AWK, Tzvetkov NT, Georgieva MG, Ognyanov IV, Kordos K, Jozwik A, Kuhl T, Perry G, Petralia MC, Mazzon E, Atanasov AG (2021) Reactive Oxygen Species and Their Impact in Neurodegenerative Diseases: Literature Landscape Analysis. Antioxid Redox Sign 34 (5):402-420. https://doi.org/10.1089/ars.2019.7952.

35. Tarafdar A, Pula G (2018) The Role of NADPH Oxidases and Oxidative Stress in Neurodegenerative Disorders. Int J Mol Sci 19 (12). https://doi.org/10.3390/ijms19123824.

36. Dabbeni-Sala F, Di Santo S, Franceschini D, Skaper SD, Giusti P (2001) Melatonin protects against 6OHDA-induced neurotoxicity in rats: a role for mitochondrial complex I activity. FASEB J 15 (1):164170. https://doi.org/10.1096/fj.00-0129com.

37. Adam-Vizi V (2005) Production of reactive oxygen species in brain mitochondria: contribution by electron transport chain and non-electron transport chain sources. Antioxid Redox Sign 7 (910):1140-1149. https://doi.org/10.1089/ars.2005.7.1140.

38. Yeh YT, Yeh H, Su SH, Lin JS, Lee KJ, Shyu HW, Chen ZF, Huang SY, Su SJ (2014) Phenethyl isothiocyanate induces DNA damage-associated G2/M arrest and subsequent apoptosis in oral cancer cells with varying p53 mutations. Free Radic Biol Med 74:1-13. https://doi.org/10.1016/j.freeradbiomed.2014.06.008.

39. Aldieri E, Riganti C, Polimeni M, Gazzano E, Lussiana C, Campia I, Ghigo D (2008) Classical inhibitors of NOX NAD(P)H oxidases are not specific. Curr Drug Metab 9 (8):686-696. https://doi.org/10.2174/138920008786049285.

40. Cornu M, Albert V, Hall MN (2013) mTOR in aging, metabolism, and cancer. Curr Opin Genet Dev 23 (1):53-62. https://doi.org/10.1016/j.gde.2012.12.005. 
41. Hardie DG, Ross FA, Hawley SA (2012) AMPK: a nutrient and energy sensor that maintains energy homeostasis. Nat Rev Mol Cell Biol 13 (4):251-262. https://doi.org/10.1038/nrm3311.

42. Chung JY, Lee SJ, Lee SH, Jung YS, Ha NC, Seol W, Park BJ (2011) Direct interaction of alphasynuclein and AKT regulates IGF-1 signaling: implication of Parkinson disease. Neurosignals 19 (2):86-96. https://doi.org/10.1159/000325028.

\section{Figures}
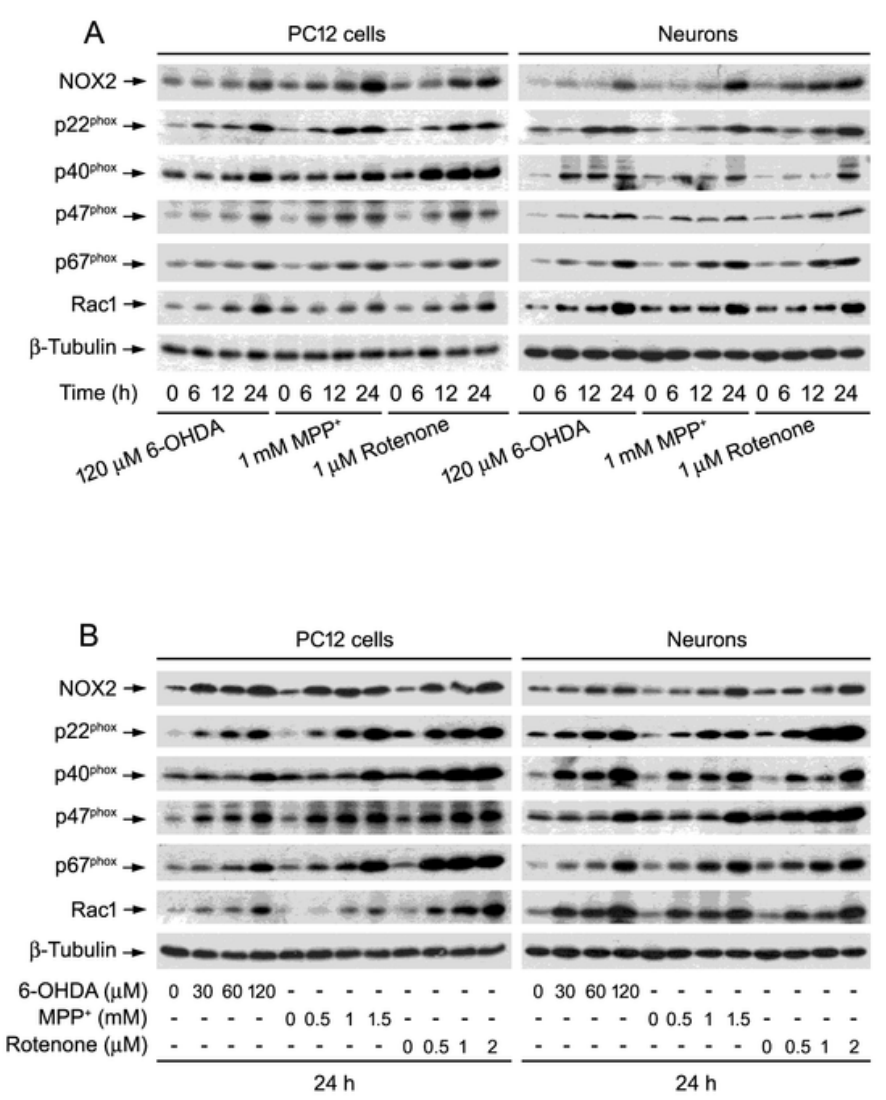
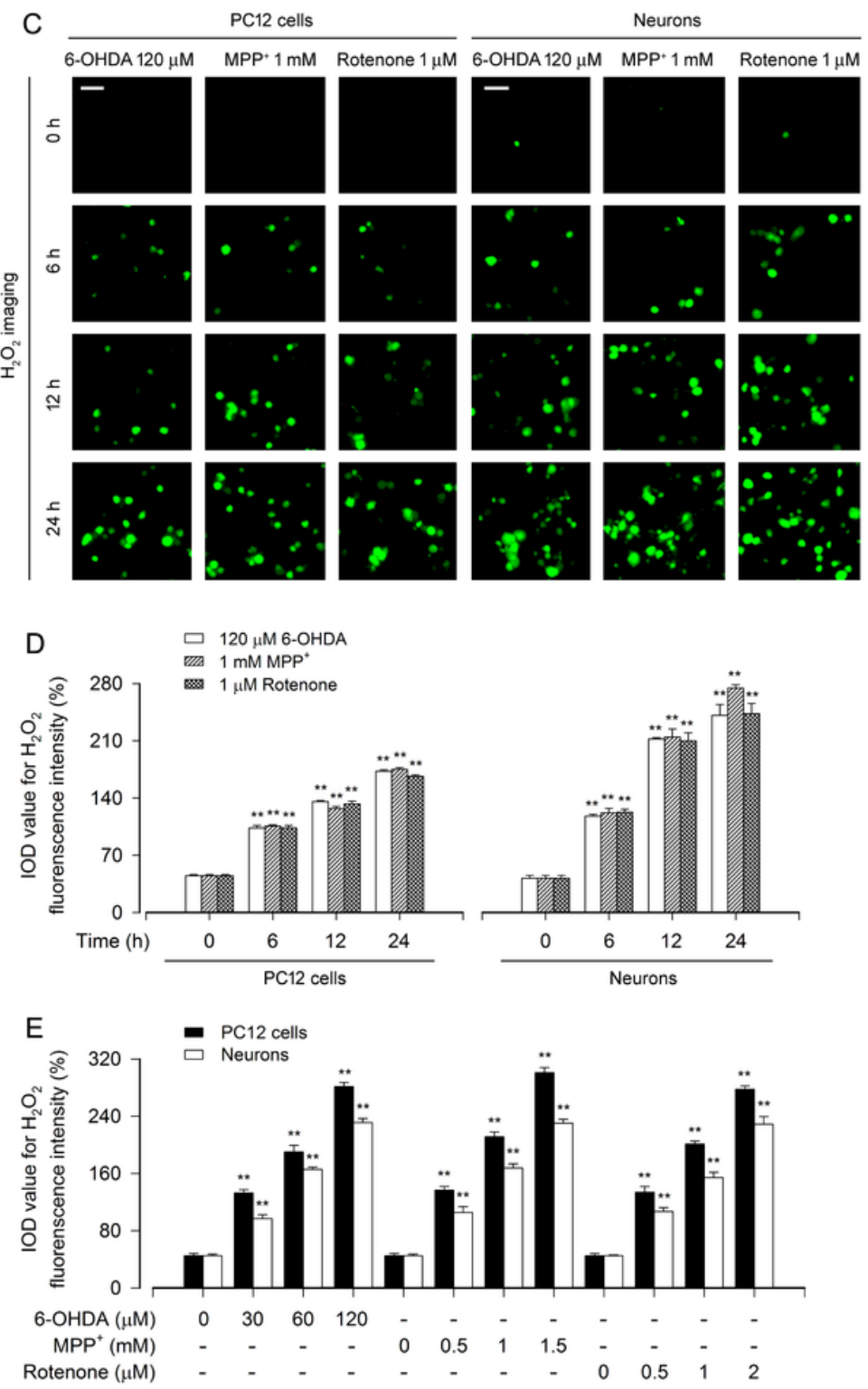

Zhang et al Figure 1

\section{Figure 1}

Upregulation of NOX2 and its regulatory proteins is associated with excessive $\mathrm{H} 2 \mathrm{O} 2$ generation in cellular models of PD. PC12 cells and primary neurons were treated with 6-OHDA (30,60 and/or $120 \mu \mathrm{M})$, MPP+ 
$(0.5,1 \mathrm{and} /$ or $1.5 \mathrm{mM})$ or rotenone $(0.5,1 \mathrm{and} /$ or $2 \mu \mathrm{M})$ for 6,12 and/or $24 \mathrm{~h}$, as described in Materials and Methods. (A and B) Total cell lysates were subjected to western blotting using indicated antibodies. The blots were probed for $\beta$-tubulin as a loading control. Similar results were observed in at least three independent experiments. (C) Intracellular $\mathrm{H} 2 \mathrm{O} 2$ was imaged (in green) using a peroxide-selective probe H2DCFDA. Scale bar: $20 \mu \mathrm{m}$. (D and E) Fluorescent intensity of intracellular H2O2 imaging was quantified. Results were presented as mean $\pm S E, n=5$. $* * P<0.01$, difference with control group.
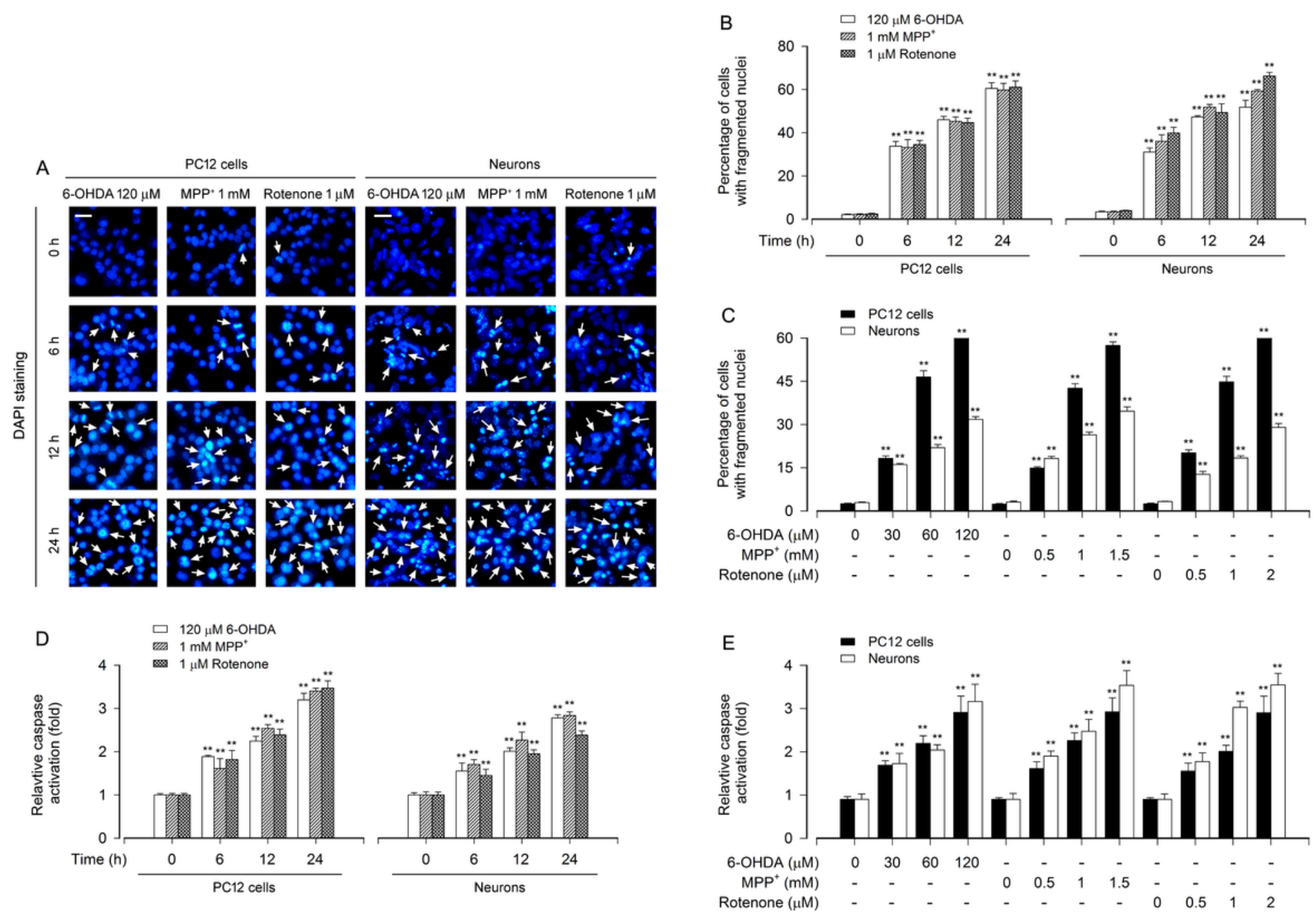

Zhang et al Figure 2

Figure 2

Neuronal apoptosis is triggered in cellular models of PD. PC12 cells and primary neurons were treated with 6-OHDA (30, 60 and/or $120 \mu \mathrm{M}), \operatorname{MPP}+(0.5,1$ and/or $1.5 \mathrm{mM})$ or rotenone $(0.5,1$ and/or $2 \mu \mathrm{M})$ for 6 , 12 and/or $24 \mathrm{~h}$. (A) Apoptotic cells were evaluated by nuclear fragmentation and condensation (arrows) using DAPI staining. Scale bar: $20 \mu \mathrm{m}$. (B and C) The percentage of cells with fragmented nuclei was quantified. ( $D$ and $E$ ) Caspase-3/7 activities were detected using Caspase-3/7 Assay Kit. Results were presented as mean $\pm S E, n=5$. ${ }^{*} P<0.01$, difference with control group. 

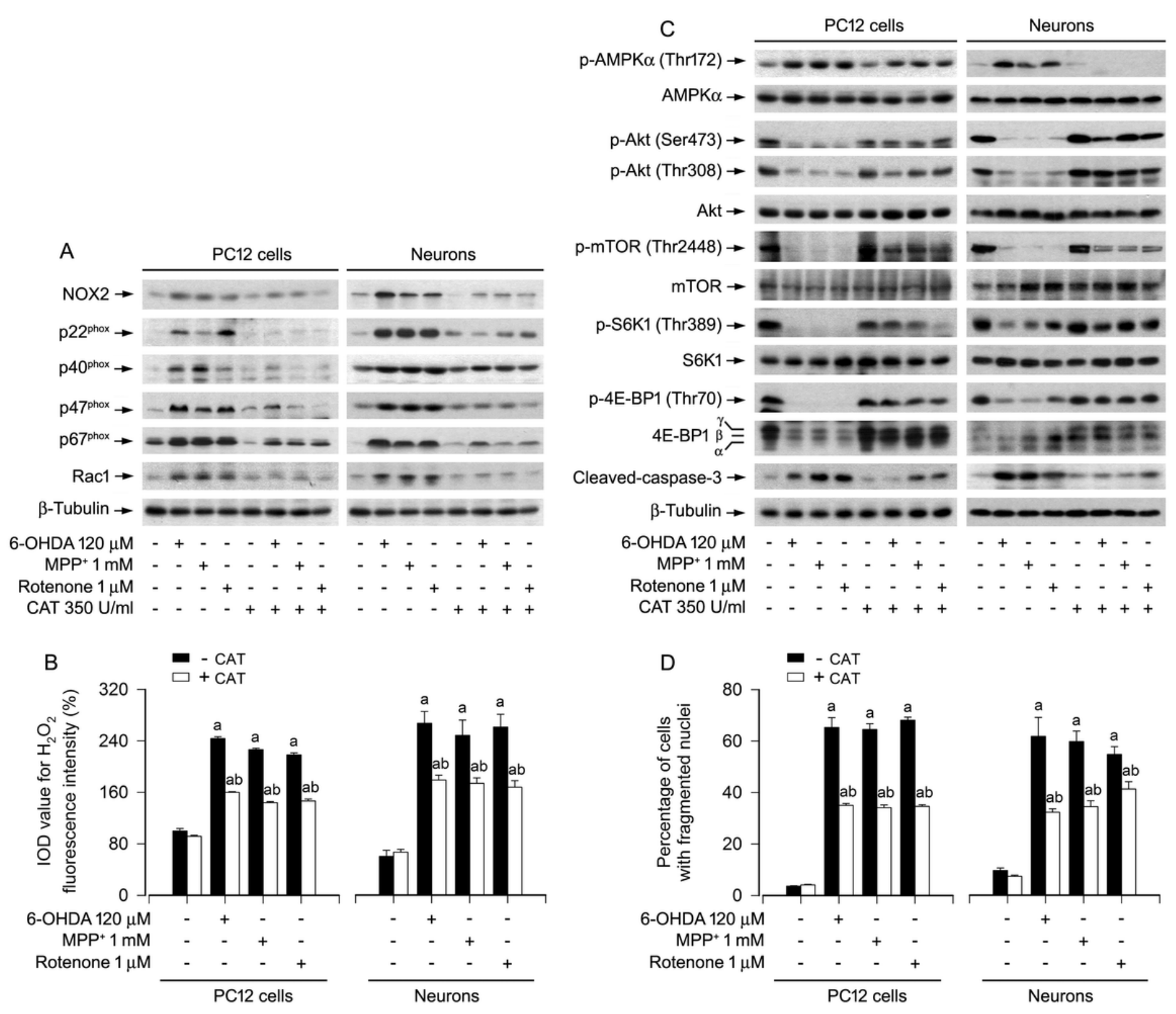

Zhang et al Figure 3

\section{Figure 3}

Scavenging intracellular $\mathrm{H} 2 \mathrm{O} 2$ with catalase ameliorates abnormal NOX2 and its regulatory proteins, as well as AMPK/Akt-mTOR signaling pathway and neuronal apoptosis in cellular models of PD. PC12 cells and primary neurons were pretreated with/without CAT $(350 \mathrm{U} / \mathrm{ml})$ for $1 \mathrm{~h}$ and then exposed to 6-OHDA $(120 \mu \mathrm{M}), \mathrm{MPP}+(1 \mathrm{mM})$ or rotenone $(1 \mu \mathrm{M})$ for $24 \mathrm{~h}$. (A and C) Total cell lysates were subjected to western blotting using indicated antibodies. The blots were probed for $\beta$-tubulin as a loading control. Similar results were observed in at least three independent experiments. (B) Intracellular $\mathrm{H} 2 \mathrm{O} 2$ was imaged and quantified using a peroxide-selective probe H2DCFDA. (D) Apoptotic cells were evaluated by nuclear fragmentation and condensation using DAPI staining. Results were presented as mean SE, $\mathrm{n}=5$. $\mathrm{aP}<0.05$, difference with control group; $\mathrm{bP}<0.05,+$ CAT group vs - CAT group. 

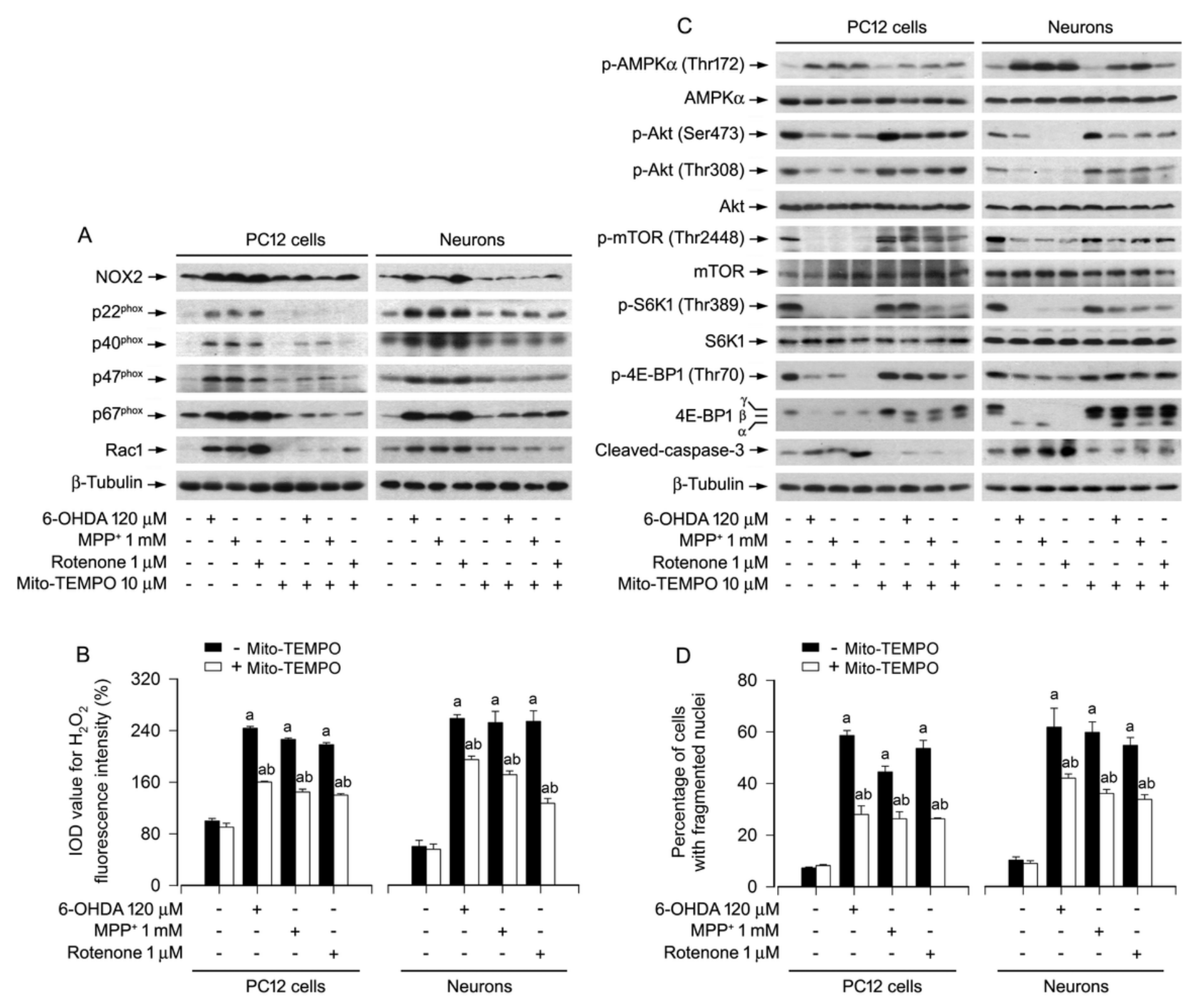

Zhang et al Figure 4

\section{Figure 4}

Scavenging of mitochondrial $\mathrm{H} 2 \mathrm{O} 2$ with Mito-TEMPO ameliorates abnormal NOX2 and its regulatory proteins, as well as AMPK/Akt-mTOR signaling pathway and neuronal apoptosis in cellular models of PD. PC12 cells and primary neurons were pretreated with/without Mito-TEMPO $(10 \mu \mathrm{M})$ for $1 \mathrm{~h}$ and then exposed to 6-OHDA $(120 \mu \mathrm{M}), \mathrm{MPP}+(1 \mathrm{mM})$ or rotenone $(1 \mu \mathrm{M})$ for $24 \mathrm{~h}$. (A and C) Total cell lysates were subjected to western blotting using indicated antibodies. The blots were probed for $\beta$-tubulin as a loading control. Similar results were observed in at least three independent experiments. (B) Cell H2O2 was imaged and quantified using a peroxide-selective probe H2DCFDA. (D) Apoptotic cells were evaluated by nuclear fragmentation and condensation using DAPI staining. Results were presented as mean SE, $n=5$. $\mathrm{aP}<0.05$, difference with control group; $\mathrm{bP}<0.05$, + Mito-TEMPO group vs - Mito-TEMPO group. 

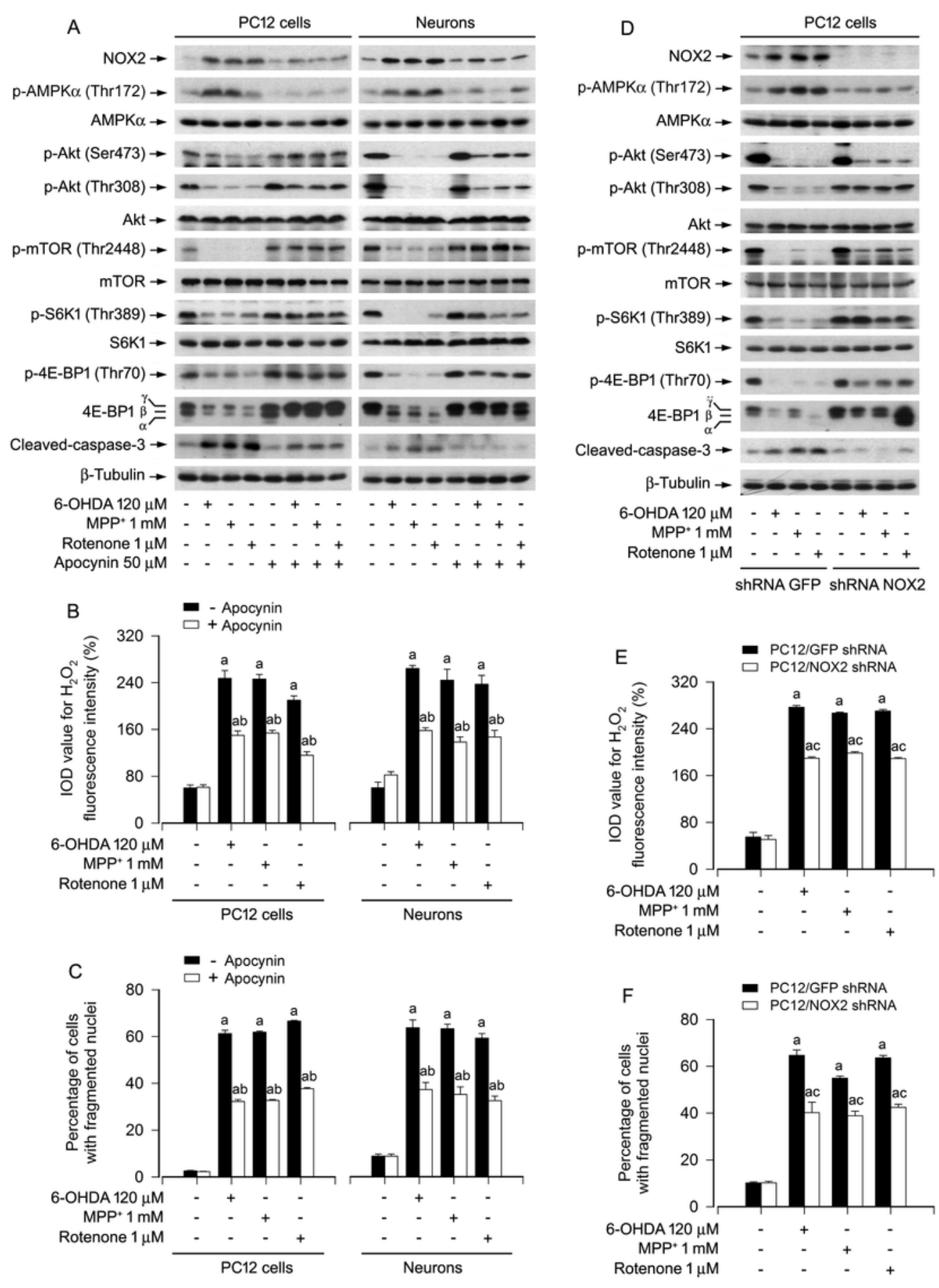

Zhang et al Figure 5

\section{Figure 5}

Pharmacological inhibition of NOX2 with apocynin or knockdown of NOX2 prevents activation of AMPK, inhibition of Akt/mTOR, generation of $\mathrm{H} 2 \mathrm{O} 2$, and neuronal apoptosis in cellular models of PD. PC12 cells and primary neurons, or PC12 cells infected with lentiviral shRNA to NOX2 or GFP (as control), respectively, were treated with/without 6-OHDA $(120 \mu \mathrm{M})$, MPP+ $(1 \mathrm{mM})$ or rotenone $(1 \mu \mathrm{M})$ for $24 \mathrm{~h}$ following pre-incubation with/without apocynin $(50 \mu \mathrm{M})$ for $1 \mathrm{~h}$, or treated with/without 6-OHDA (120 
$\mu \mathrm{M}), \mathrm{MPP}+(1 \mathrm{mM})$ or rotenone $(1 \mu \mathrm{M})$ for $24 \mathrm{~h}$. (A and D) Total cell lysates were subjected to western blotting using indicated antibodies. The blots were probed for $\beta$-tubulin as a loading control. Similar results were observed in at least three independent experiments. (B and E) Intracellular $\mathrm{H} 2 \mathrm{O} 2$ was imaged and quantified using a peroxide-selective probe H2DCFDA. ( $C$ and F) Apoptotic cells were evaluated by nuclear fragmentation and condensation using DAPI staining. Results were presented as mean SE, $n=5$. $\mathrm{aP}<0.05$, difference with control group; $\mathrm{bP}<0.05$, + Apocynin group vs - Apocynin group; $\mathrm{cP}<0.05$, NOX2 shRNA group vs GFP shRNA group.

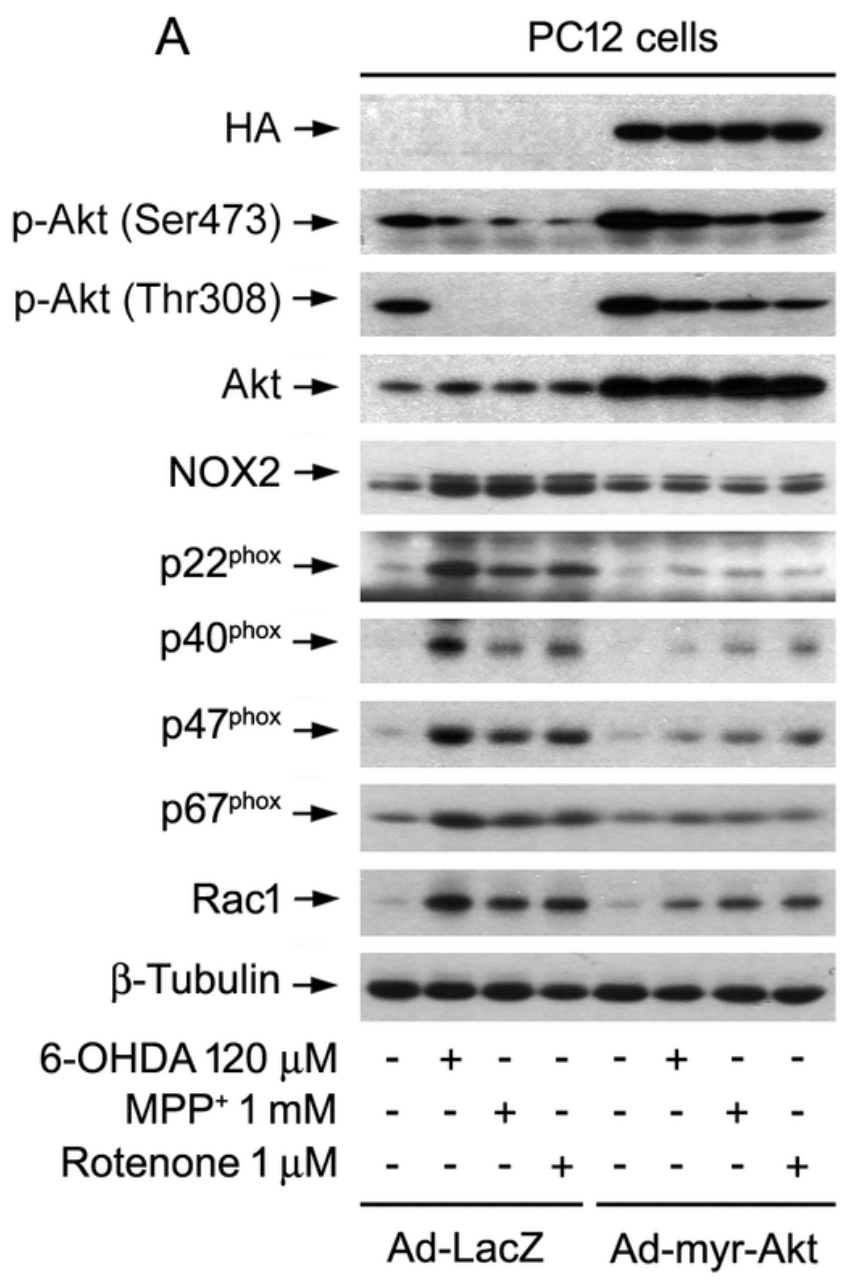

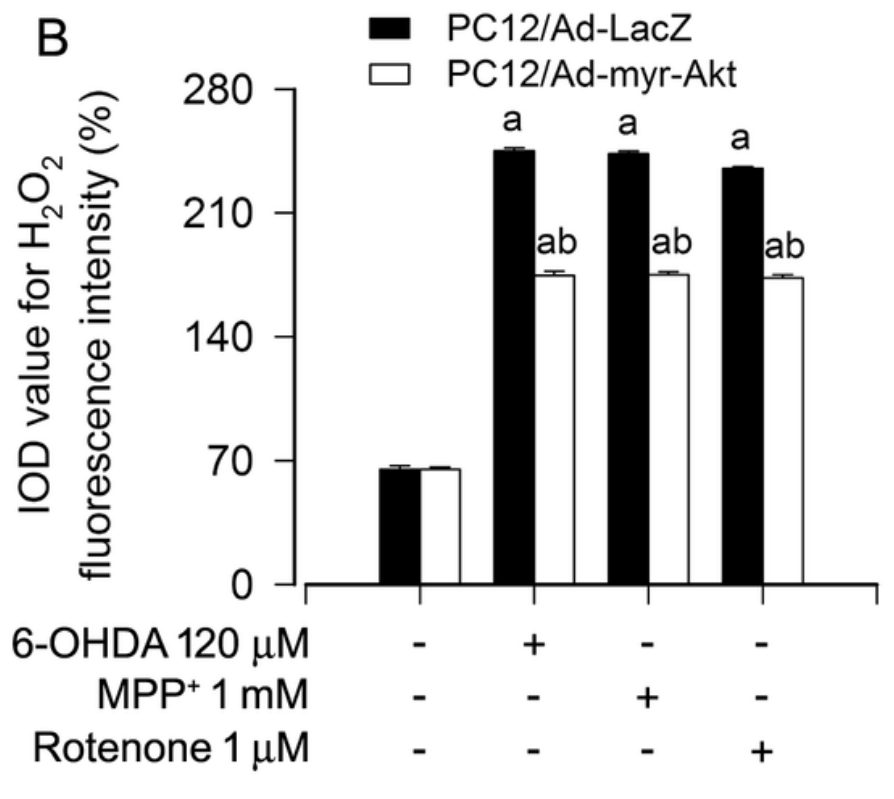

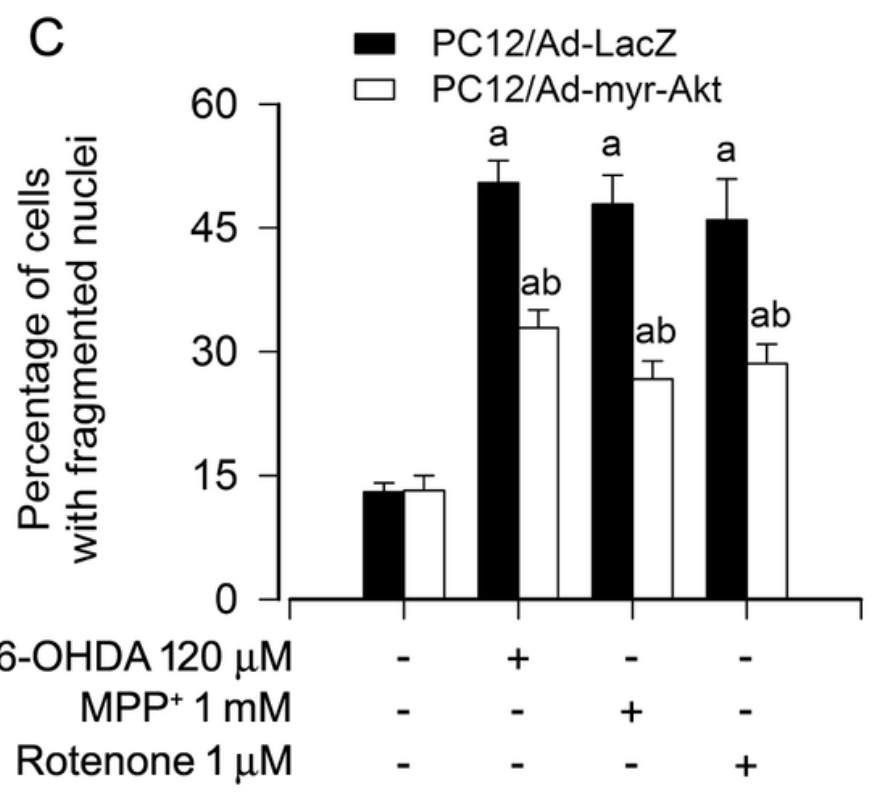

Zhang et al Figure 6

Figure 6 
Ectopic expression of constitutively active Akt attenuates upregulation of NOX2 and its regulatory proteins, generation of $\mathrm{H} 2 \mathrm{O} 2$, as well as neuronal apoptosis in cellular models of PD. PC12 cells, infected with Ad-myr-Akt or Ad-LacZ (as control), respectively, were treated with/without 6-OHDA (120 $\mu \mathrm{M}), \mathrm{MPP}+$ $(1 \mathrm{mM})$ or rotenone $(1 \mu \mathrm{M})$ for $24 \mathrm{~h}$. (A) Total cell lysates were subjected to western blotting using indicated antibodies. The blots were probed for $\beta$-tubulin as a loading control. Similar results were observed in at least three independent experiments. (B) Intracellular $\mathrm{H} 2 \mathrm{O} 2$ was imaged and quantified using a peroxide-selective probe H2DCFDA. (C) Apoptotic cells were evaluated by nuclear fragmentation and condensation using DAPI staining. Results were presented as mean $\mathrm{SE}, \mathrm{n}=5$. aP $<0.05$, difference with control group; bP $<0.05$, Ad-myr-Akt group vs Ad-LacZ group. 

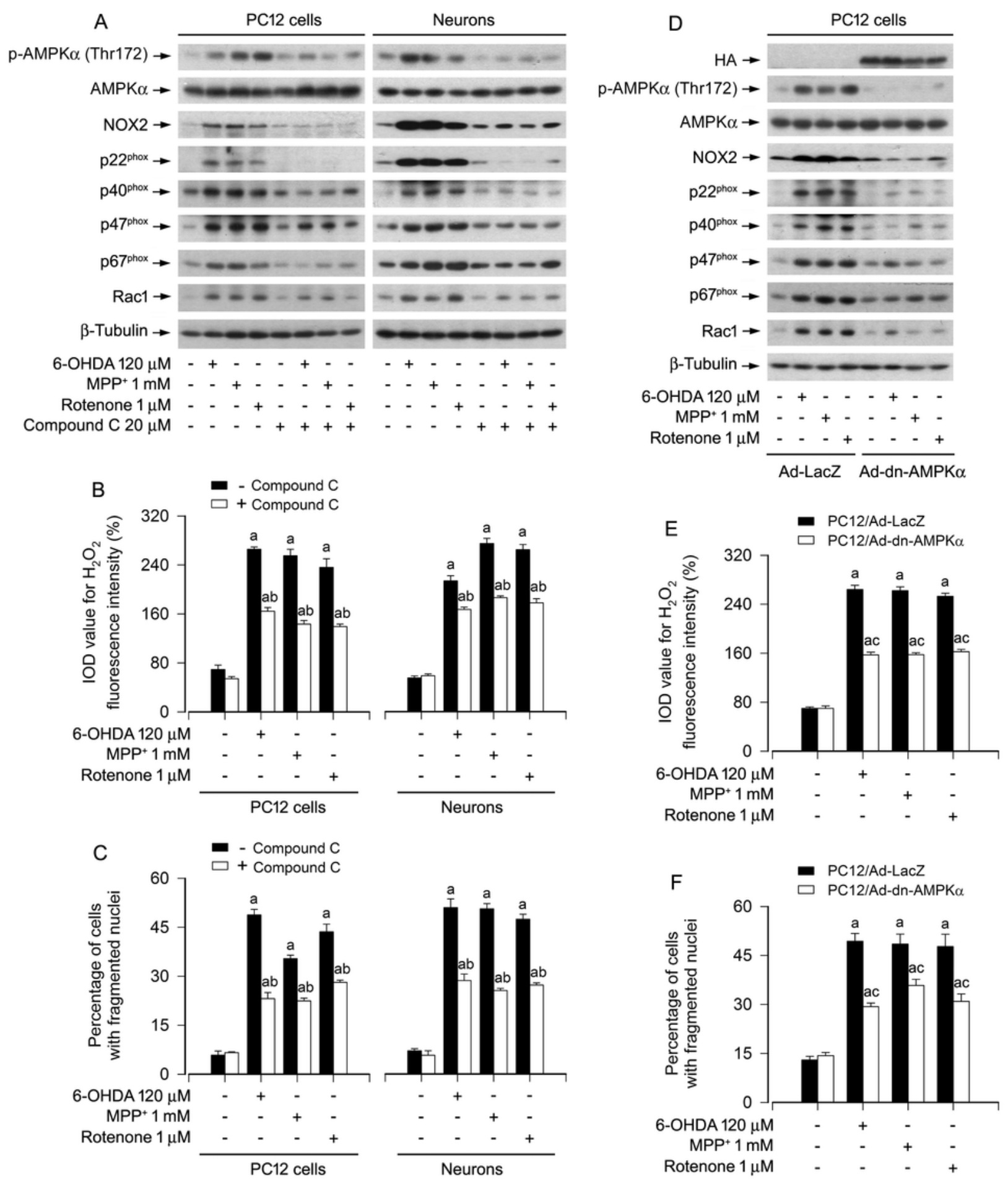

Zhang et al Figure 7

\section{Figure 7}

Pharmacological inhibition of AMPKa with compound $\mathrm{C}$ or expression of dominant negative AMPKa attenuates upregulation of NOX2 and its regulatory proteins, generation of $\mathrm{H} 2 \mathrm{O} 2$, as well as neuronal apoptosis in cellular models of PD. PC12 cells and primary neurons, or PC12 cells infected with Ad-dnAMPKa or Ad-LacZ (as control), respectively, were treated with/without 6-OHDA (120 $\mu \mathrm{M}), \mathrm{MPP}+(1 \mathrm{mM})$ or rotenone $(1 \mu \mathrm{M})$ for $24 \mathrm{~h}$ following pre-incubation with/without compound $\mathrm{C}(20 \mu \mathrm{M})$ for $2 \mathrm{~h}$, or treated 
with/without 6-OHDA $(120 \mu \mathrm{M}), \mathrm{MPP}+(1 \mathrm{mM})$ or rotenone $(1 \mu \mathrm{M})$ for $24 \mathrm{~h}$. (A and D) Total cell lysates were subjected to western blotting using indicated antibodies. The blots were probed for $\beta$-tubulin as a loading control. Similar results were observed in at least three independent experiments. (B and $E$ ) Intracellular $\mathrm{H} 2 \mathrm{O} 2$ was imaged and quantified using a peroxide-selective probe H2DCFDA. (C and F) Apoptotic cells were evaluated by nuclear fragmentation and condensation using DAPI staining. Results were presented as mean $\mathrm{SE}, \mathrm{n}=5$. $\mathrm{aP}<0.05$, difference with control group; $\mathrm{bP}<0.05,+$ Compound $\mathrm{C}$ group vs - Compound C group; $\mathrm{cP}<0.05$, Ad-dn-AMPKa group vs Ad-LacZ group.

\section{PD toxins (6-OHDA, MPP+, Rotenone )}

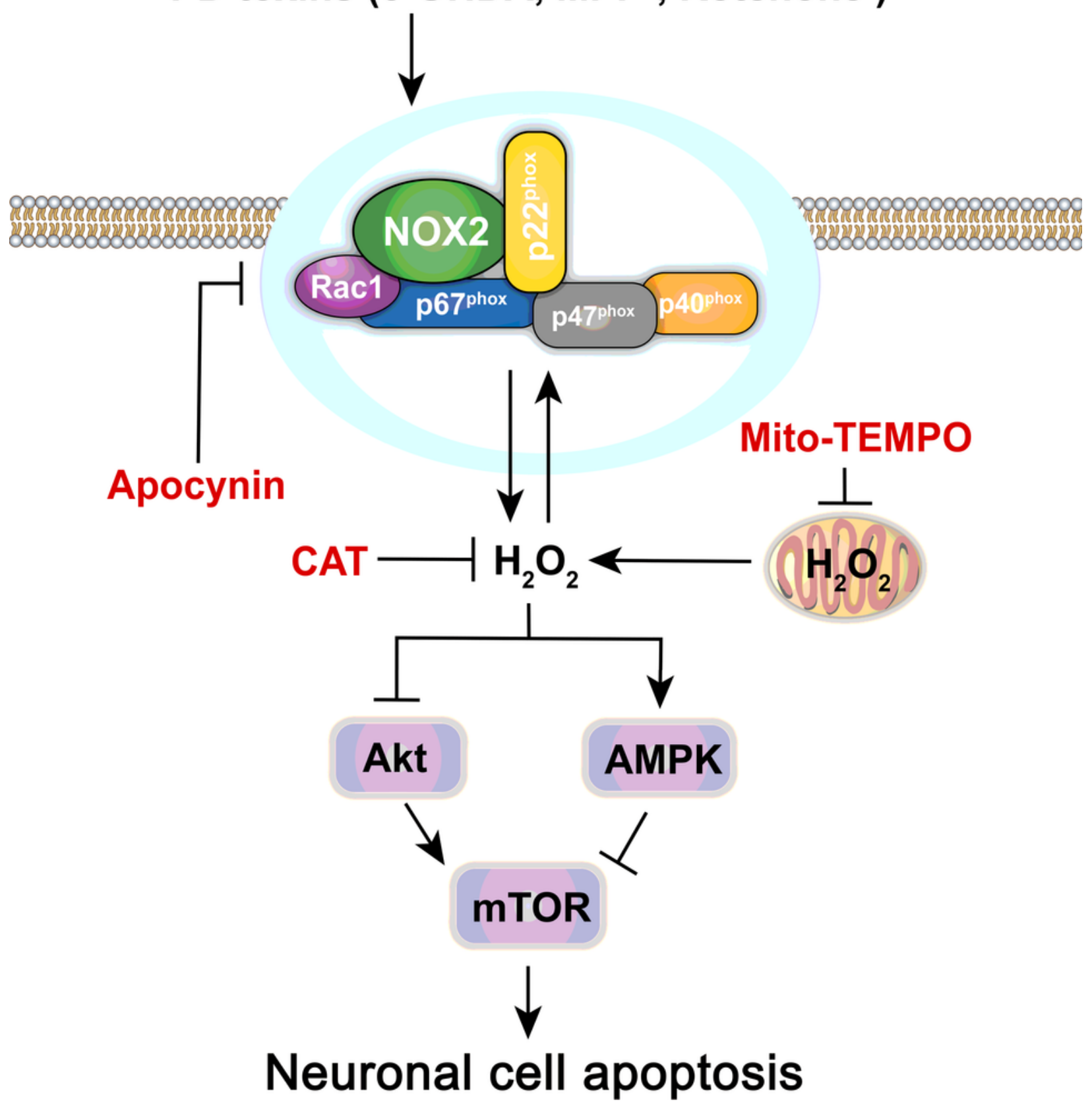

Zhang et al Figure 8 


\section{Figure 8}

A schematic model of how PD toxins (6-OHDA, MPP+ or rotenone) induce NOX2-derived $\mathrm{H} 2 \mathrm{O} 2$ leading to neuronal apoptosis. PD toxins upregulate the expression of NOX2 and its regulatory proteins, and thus evoke intracellular $\mathrm{H} 2 \mathrm{O} 2$ and concomitant mitochondrial H2O2. This results in activation of AMPK and inactivation of Akt, convergently inhibiting the MTOR pathway contributing to apoptosis in neuronal cells. 